\title{
Information from Theory towards Science
}

\author{
Jozef Novak-Marcincin ${ }^{1}$, Adrian Nicolescu ${ }^{2, *}$, Mirela Teodorescu ${ }^{3}$ \\ ${ }^{1}$ Technical University of Kosice, Slovakia \\ 2University of Craiova, 13 A. I. Cuza Street, 200585, Craiova, Romania \\ 3 Independent researcher, Craiova, Romania \\ *E-mail address: a86iorgulescu@yahoo.com
}

\begin{abstract}
Information from Theory towards Science, the professor Stefan Vlăduţescu's book from University of Craiova, is a confirmation of high intelligence level and propensity of author's cognition. From various semiotic materials (words, images, gestures, drawings, etc.), following certain principles, under different procedures (operations, actions, movements, maneuvers, mechanisms, strategies) using means (languages, codes, subcodes) and specific tools (knowledge, concepts, categories) adapted aim between earth (with autocorrection by feedback) and firmament (as anticipation by feed-forward) rises an imposing edifice, a cognitive construction: this is information. It has systemic and procedural character and is organized on four coordinates: metric, semantic, structural and pragmatic.
\end{abstract}

Keywords: information, communication axioms, communication models, information coordinates

\section{INTRODUCTION}

The concept that information is the message has different meanings in different contexts. Thus the concept of information becomes closely related to notions of constraint, communication, control, data, form, instruction, knowledge, meaning, understanding, mental stimuli, pattern, perception, representation, and entropy. So, either it would be the type, amount, mode of production, the means or the transfer channel, the information remains, with the self theoretical -identical, cognition and construction, conceptual organization of the world and fundamental Gnosis practice and all of these are presented us by Professor Vlăduţescu through his book, Information from Theory towards Science.

The book is structured in 14 chapters through which the reader enter in a complex world of technical data, neutrosophical messaging, social representation of information, information-energy-matter, relation between communication and information, information as the third generation of world domination, fundamental models of communication and information, communicational and informational process, communicational and informational system, constructive device of information by noetic material, carrier signal, communication axioms and principles, information coordinates, information classification.

The approached theme is generous, the author presented for each one researches of reputed scientist from ancient tine until now. The communication science is relative a new science, it had a quickly development, information through communication is present in all sciences, domains, areas, levels because "the man communicates even he wants or does not want, sometimes a voluntary basis, sometimes unintentionally", says the first axiom of communication. To be accepted as science, communication had to prove its completitude 
and consistency. Information from Theory towards Science, is a study through which professor Vlăduţescu demonstrates the force and the role of information in communication science.

"The overwhelming majority of research on a topic is done in absence of any consciousness of completeness of the reading and subject capitalization reference. An important part of what remains explicitly rejects the completeness according to the idea of satiety and of their enough brought by proper zetetic engagement, explorative. Remains that, in an era in which a theme in written increasingly longer, one who reads addresses on time without thought of remorse, only an alleged enough" concludes professor Vlăduţescu.

We have to mention that professor Vlăduţescu, most of subjects of this book, has renewed in articles or in books, updated by his researches, with the newest information and own visions on items.

\section{INFORMATION, ENERGY, MATTER, CONCEPT}

Nothing is more useful and practical than a good theory. Professor Vlăduţescu defines the necessity and importance of a concept along the time. The basis of such reasoning, permanently installed as true in our century put it in the history of Plato's ideas through the voice of Socrates, which can be even Socrates, states: "People called us to discuss on the mean to make their children better, planting the virtue in their soul. In this case, does not have we to have first the notion of what is the virtue? "(Plato, Lahes 190b). Virtue cannot be taught or learned, whether there is not before realized the concept of "virtue". Similarly, you cannot find information in the absence of a concept of "information". Cognition without concept is inexorably subject to error. The idea is found in Immanuel Kant: "All cognition requires a concept, however uncertain" (Kant, 1994, p. 141), as in Hegel: "Anything is not reality made by the concept itself, is existing in fact, transient, an external contingency, opinion, deception. (...) In cognition, the need for a concept is the main thing" (Hegel, 1996, p. 21 and p. 23). The concept of naive representation is inconsistent, that of the scientific representation is productive and offensive. Regarding the essence and place of information in the world system, things were not always clear, and in part they have not come to be fully clarified and rationally not proven even today. Something has remained stable and undisputed since the first steps in domain where we are: the information exist, is an event of Gnosis practice without any doubt. In connection with the inevitability of information, concern to the limit of philosophy, were formulated, from the strengthen of the concept in the first part of the twentieth century, two theories: gnoseological and ontological. Ontological Theory focuses on the idea that information is an imanent quality of the matter, which information subject notifies it, discovers and expresses it or anticipates it, imagines it and formulates it. Gnoseological Theory qualifies information as secondary related to conscious and, as a phenomenon, related to the subject. It is not an objective attribute of matter, but a relation between subjects, mediated by a material carrier. Information, phenomenon proper human, attribute of matter or feature of the objects, is a totally subjective cognitive activity. Although communication and information are inseparable in their relationship, shows the author, first is determinative, it conditions the second and has precedence both ontogenetic and filogenetic. Thinking and communication were formed and evolved together. The information is on one side of his cognition, conceptual gnoseological organization of the 
world, which has to be defined as knowledge. So, professor Vlăduţescu shows that "communication is thus a process which information is content, one cannot be understood without the other, and the study of one and the other one should be only one. Any communication can be a medium for information dissemination. When the informational meaning (new relevant, meaningful and useful) assert as objects of communicative transfer, the communicative activity turns into informational activity.

\section{COMMUNICATION MODELS, PROCESSES, AXIOMS, PRINCIPLES}

A large space is reserved by the author to define the communication as system, by models, processes, axioms, principles. Cognitive approach, either practical deployment or activity purely theoretical, tends towards the constitution of a representations about the cognitive object. Once triggered operation, effects occur irrepressible: representation and conceptualization appear as implicit in Gnosis practice and explicit theoretical journey. The image-model of communication and information represented in the history of informational ideas an inescapable imperative. The structure of communication and information is defined in theories and re-defined by comparison, abstraction and generalization within a science.

The object knowing means knowing of its mode of constitution and its components. Any serious research should be based on a model and meet an objective. History of communication and information has been marked by several models. The author presents communication models as structure, relation with other systems, merits, demerits, lacks, novelty. Among the described models is Shannon-Weaver Model, one of the most comprehensive model available added according to each system involved in communication process. Are mentioned sociological models such as Schram's model, Gerbner's model, R. Jakobson's linguistic model, Al. Spataru's Romanian idea to call received information "transinformation" because entering data into a reasoning, if for a "restricted communication" as information is (informational meaning must have certain characteristics) is required as counter-concept "transinformation", where for "communication" such a concept of process is more necessary. The information is part of the communication and information theory, similar to a part of communication science.

Communication, as a system of self-regulation, self-organizing, develops two goals that through automation strategies can become also mechanisms. The strategies well known are feed-back and feed-forward, the relation of present with the past and the future. The author mentions also that information is a product of producer-consumer type. Absolutely nothing occurs by chance. The constraints are taken into account in producing the information speak for themselves on the "conformist" side of product and production, about which movement information is intended to reach the consumption space: that of intended receptor (recipients, arhireceptors, concerned observers). Communication, as a system, is an ad-hoc assembly or organized institutional of interdependent elements, being in manifest interacting (production, reception, processing and transmission of meaning information) or latent, which develops social functions or personal to achieve goals. It is ordered and organized in accordance with the functions that it performs. Among the phenomena of communication, the informational are indisputable distinguished, not monadic connotation, but their substantial independence. Communication production is also one of the information. The surplus comes from there that information is a producer, 
and communication product. The information is continually, communication is performed. Producer is a production on going to the product, where it will never arrive if it is wanted to remain information. If communication, the axioms help information construction but they are not enough. For the latter are necessary "sentence" structure, organization principles of noetic matter, of meanings.

Information themselves have structural parameters that give them relevance: unity, novelty, semantic coherence and cohesion, closure related to the base of knowledge and openness in relation to the universe of knowledge, semiotic articulation, primer of interpretation and trace of construction principles action. Information is not matter and not energy. It is itself a separate entity unique, fundamental and indestructible. A Latin principle tells us that the affirmation precedes negation. For information, however, is more profitable to begin to delimit it by the negation. Information is neither object nor naked pressure. It is a Gnosis event, an order placement in disorder, in the chaos of the world, a representation of variability and indeterminacy. Information appears as a complex construction. Its ascension process is the result of elements interaction that constitutes the production system or consumption, modeled by a structure of finalities. Objective cannot raises without application of know-how and certain production and consumption laws. By analogy with the dictum "there is nothing in the intellect, if there was not first in the senses", generally, we can say that is nothing in conscious, intentional and gnoseological to humans if there earlier are not concepts through which to exist. As principles are mentioned by the author: principle of impossibility to not inform yourself, principle of meaning, principle of object variability and informational signal, principle of informational selectivity, principle of information loose, principle of conformity benefit.

\section{INFORMATION COORDINATES}

Information conceiving as building creates a spatial-mechanical perspective quadruple coordinated: metric, structural, semantic and pragmatic. The first of coordinate is quantitative, the other three - qualitative. They appear as autonomous relationship. Quantity is the category that designs experimental determinations by number, grade, size, stretching etc. Quantitative determinations can be known by measurement and calculation. Quantity is, within certain limits, the inextricable relation with the quality of quantitative determinations. It expresses the synthesis of aspects and the fundamental features of objects, phenomena and processes. Quality changes means radical transformation of the object. Quality is proper to an object or phenomenon. Any object or phenomenon involves a unity of qualitative and quantitative measurements. A key measure of information is entropy, which is usually expressed by the average number of bits needed to store or communicate one symbol in a message. Entropy quantifies the uncertainty involved in predicting the value of a random variable, it measure the disorder of an informational system. Quality is constituted as a heuristic synthesis of significance, relevance and usefulness. Simplified, quality = "significance of element within the system" $\mathrm{x}$ "its relevance in relation to consumer knowledge base" $\mathrm{x}$ "utility in achieving the goal though which in the terms of informational grid was given relevance". Quality is a product of factors rather than a summation of terms. For quality, novelty is mandatory, but the size, its amplitude - by no means decisive. Quality is based on quantity, cannot exist without it, and the reverse is perfectly valid: no novelty without any quality. It could be defined as 
functionally indestructible. The quantity of information and quality of information underlie theoretically the value. Their coordinated assumption is that ontological information already exists when it raises the question of quantity and quality.

\section{CONCLUSIONS}

Through a rigorous conceptualization of the object domain of information, by creating a production information device and shaping of a informational consumer device (called grid), by the foundation of a method (as "procedure by laws", as says Im. Kant) formed of operations, actions, tactics (moves and maneuvers) strategies and mechanisms from a simple theory as a natural evolution, can be made the step to an information science. "Even though our approach did not entirely to achieve the great passage, undoubtedly the allocated energy and effort put generated, in part necessary combustion, that triggered fission that carefully monitored and by later sustained contributions supported to lead to the transformation of information theory in science" sustains professor Vlăduţescu. After reading the professor Vlăduţescu's book, Information from Theory towards Science, it can be asserted the Talleyrand's statement: "Fear of first impression, it is the best".

\section{References}

[1] Ştefan Vlăduțescu (2002). Informatia de la teorie către știință. Propedeutică la o științăa a informației. București: Editura Didactică și Pedagogică.

[2] Oprea-Valentin Buşu, Mirela Teodorescu, Daniela Gîfu, International Letters of Social and Humanistic Sciences 27 (2014) 82-93.

[3] Andrzej Borowski, International Letters of Social and Humanistic Sciences 14 (2014) 33-41.

[4] Ioan Constantin Dima, Ştefan Vlăduţescu (2012). Persuasion elements used in logistical negotiation: Persuasive logistical negotiation. Saarbrucken: LAP Lambert Academic Publishing.

[5] G.W.F. Hegel (1996). Principiile filosofiei dreptului. Bucureşti: Editura Iri.

[6] Immanuel Kant (1994). Critica raţiunii pure. Bucureşti: Editura Iri.

[7] Andrzej Borowski, International Letters of Social and Humanistic Sciences 14 (2014) 7-17.

[8] Paula Bajdor, Iwona Grabara, Journal of Studies in Social Sciences 7(2) (2014).

[9] Ştefan Vlăduţescu, American International Journal of Contemporary Research 3(10) (2013).

[10] D. Gîfu, D. Ionescu, M. Teodorescu, International Letters of Social and Humanistic Sciences (26) (2014) 18-28.

[11] Daniela Gîfu, Mirela Teodorescu, Dan Ionescu, International Letters of Social and Humanistic Sciences 17 (2014) 61-69.

[12] Ștefan Vlăduțescu, International Letters of Social and Humanistic Sciences 10 (2014) $100-106$.

[13] Florentin Smarandache, Ștefan Vlăduțescu, Alina Țenescu (2014). Current Communication Difficulties. Craiova/Columbus: Sitech/Zip Publishing.

[14] Andrezj Borowski, International Letters of Social and Humanistic Sciences 6 (2013) 86-90. 
[15] Janusz Grabara, Michal Kolcun, Sebastian Kot, International Journal of Education and Research 2(2) (2014).

[16] Ștefan Vlăduțescu, International Letters of Social and Humanistic Sciences 15(2) (2014) 164-170.

[17] D. Gifu, O. V. Buşu, M. Teodorescu, International Letters of Social and Humanistic Sciences (27) (2014) 82-93.

[18] Andrezj Borowski, International Letters of Social and Humanistic Sciences 4 (2013) 70-74.

[19] Bartłomiej Okwiet, Alina Țenescu, Adrian Nicolescu (2014). Social, communicational and law responsibility in multinational companies. Topical Communication Uncertainties, 149.

[20] Andrezj Borowski, International Letters of Social and Humanistic Sciences 2 (2013) 56-60.

[21] A. Sandu (2009). Tehnici afirmativ-apreciative. O sociopedagogie a succesului. Lumen.

[22] Antonio Sandu, Elena Unguru (2014). Acțiune comunicativă, justiție deliberativă și restaurativă. București: Editura Tritonic.

[23] Ștefan Cojocaru (2005). Metode apreciative în asistența socială: ancheta, supervizarea, studiul de caz. Polirom.

[24] Sebastian Kot, Beata Ślusarczyk (2014). IT Role in Supply Chain Collaboration. Current Communication Difficulties, 165.

[25] Florentin Smarandache, Stefan Vladutescu, Revista de Cercetare şi Intervenţie Socială, (46) (2014) 243-254.

[26] Ştefan Vlăduţescu, European Scientific Journal 9(32) (2013).

[27] Andrzej Borowski, International Letters of Social and Humanistic Sciences 3 (2013) 46-53.

[28] Ștefan Vlăduțescu, Florentin Smarandache, Daniela Gîfu, Alina Țenescu (2014). Topical Communication Uncertainties. Craiova/Columbus: Sitech/Zip Publishing.

[29] Andrzej Borowski, International Letters of Social and Humanistic Sciences 14 (2014) 7-17.

[30] Joanna Tabor, Journal of Management Studies 9(1) (2014) 233-243.

[31] A. Caras, A. Sandu, Procedia-Social and Behavioral Sciences 149 (2014) 142-151.

[32] A. Sandu, Postmodern Openings (3) (2014) 49-66.

[33] Ștefan Vlăduțescu, International Letters of Social and Humanistic Sciences 7 (2014) 8-13.

[34] J. H. Gasderell, International Letters of Social and Humanistic Science 22 (2014) 8591.

[35] Florentin Smarandache, Ștefan Vlăduţescu, Mirela Teodorescu (2014). Communication of uncertainties in Neutrosophy. Topical Communication Uncertainties, 9.

[36] Marieta Stanciu, Madalina Giorgiana Mangra (2014). Social Security System And Pension Systems-Pilons Of Social Cohesion. Annals of University of Craiova-Economic Sciences Series.

[37] Janusz Grabara, Paula Bajdor (2014). Organizational culture difficulties in SME enterprises. Topical Communication Uncertainties, 42. 
[38] Ștefan Vlăduțescu, International Letters of Social and Humanistic Sciences 15(2) (2014) 164-170.

[39] Marin Drămnescu (2014). Communication. Political speech. Populist speech. Topical Communication Uncertainties, 242.

[40] M. G. Mangra, E. A. Cotoc, A. Traistaru, Journal of Studies in Social Sciences 6(1) (2013).

[41] Vladimir Aurelian Enăchescu (2014). Teaching-communication barriers. Analysis and solutions. Current Communication Difficulties, 277.

[42] A. C. Strunga, C. M. Bunaiasu, Revista de cercetare şi intervenţie socială (40) (2013) 61-77.

[43] Max G. Craig, Journal of Studies in Social Sciences 8(1) (2014).

[44] Ştefan Vlăduţescu, European Scientific Journal 9(32) (2013).

[45] S. Cojocaru, A. Sandu, S. Ponea, Social Research Reports 8 (2010).

[46] Andrzej Borowski, International Letters of Social and Humanistic Sciences 27 (2014) $100-110$.

[47] Jason L. Powell, International Letters of Social and Humanistic Sciences 17(1) (2014) $1-60$. 